after World War II. He received his bachelor's degree in social science from California State University, Fresno, in 1950 and his master's in political science from Harvard in 1954. He then entered the Marine Corps, graduating first in his class from Officer Candidate School at Quantico in 1955, and was commissioned and stationed at Camp Pendleton. After two years of active duty, he joined the reserves and the California State University, Los Angeles, faculty in 1957 . He continued in the reserves, rising to the rank of major, until 1967. He received his Ph.D. in political science from Harvard University in 1971.

At Cal State, Los Angeles, he taught a variety of courses in the American and California government and politics areas, specializing toward the end of his career in a lower division writing and research seminar required of all political science majors. He chaired the department of political science from 1977 to 1980, the era when Proposition 13 was passed and led to many cutbacks, and he was associate chair both before and after his term as chair. For many years, he was the interdisciplinary social science adviser. In many ways, he was a faculty member's faculty member, the only person who, in the memory of the department, ever systematically straightened out the student files, and a wise adviser to several department chairs. His knowledge and advice regarding department, school, and university internal politics was superb. Several faculty from his era remember his wise counsel and encouragement of good quality instruction and rigorous research. Many faculty who served with Stan on campus committees may remember his wonderfully roundabout mode of speech, in which he would discuss a problem by talking about something seemingly unrelated, and then several minutes later, you would realize that he had been circling the problem, producing insights you never realized were there.

He sat on several university-level committees, including faculty affairs, the committee on committees, fiscal affairs, and academic freedom and professional ethics, as well as numerous school-level committees and every committee in the department. He advised in the university's academic advisement and information center. He was a member of the Advisory Committee to the Joint Legislative Committee for the Revision of the Election Code of the California state senate and assembly in 1973 to 1974, as well as the Los Angeles
County Citizens Planning Council in 1972 to 1973 . He was an active member of the AAUP campus chapter and served on its executive committee.

He authored articles on cross-filing, the history of the Republican party in California, and partisanship in the U.S. Senate in the nineteenth century in the Western Political Quarterly, the Journal of Interdisciplinary History, and Social Science History.

He is survived by his wife, Carol, three brothers, four children, 11 grandchildren, and two great-grandchildren. A memorial service was held on February 14 at Palmdale United Methodist Church in Palmdale.

J. Theodore Anagnoson California State University, Los Angeles

\section{ARTHUR KALLEBERG}

Our friend and colleague, Arthur Kalleberg, passed away peacefully on October 3 , 2009, at the age of 78 . He had been in retirement for the past 15 years. He was born in 1931 in Minneapolis and spent his youth there. After serving in the Navy during the Korean Conflict, he attended the University of Minnesota, where he received his BA (with honors), MA, and Ph.D.

He was an instructor at Mt. Holyoke College from 1960 to 1961 and served on the faculty of the University of Missouri-Columbia from 1961 until his retirement. He was a fellow at the Center for Advanced Studies in the Liberal Arts/Humanities at Wesleyan University from 1963 to 1964 . He also served as a visiting associate professor at the University of Minnesota from 1967 to 1968.

Professor Kalleberg had a reputation as a good and conscientious teacher at both the undergraduate and graduate levels. $\mathrm{He}$ was a political theorist through and through and taught courses from classical to contemporary theory. He was always available to meet with students to answer questions they had about political theory and the theorists who spun them. His course in Scope and Methods was a pillar in our graduate program and introduced students to the rigors of research in the discipline.

Professor Kalleberg was a substantial scholar. His publications addressed topics that were timely and appeared in among other sources, World Politics, The American Political Science Review, The Journal of Politics, and Polity.

He served as the director of graduate studies from 1969 to 1970 and as chair of political science from 1970 to 1973. As an administrator, he was the epitome of fair-mindedness; as a faculty member, he brought sound judgment to collegial discussions. Professor Kalleberg was always available to listen to the concerns of others, and he was intensely devoted to the department. Late in his career, when no other faculty member came forward to be graduate director, he volunteered and served another three years in that office, even though he had already had that experience. In the department and on campus, he spoke up for an expanded role of faculty in governance and for sound academic values.

He was awarded an American Council of Learned Societies Fellowship for the 1963-64 school year. In 1981, he was awarded the Byler Distinguished Professor Award and appointed to the Frederick A. Middlebush Chair in Political Science in recognition for excellence in teaching and research, a post which he held from 1980 to 1983.

Professor Kalleberg was an avid photographer and won several awards for his work in this area. He is survived by a son and daughter and six grandchildren. Joan, his wife of 50 years to whom he was devoted, passed away two months following his death.

Dean L. Yarwood Professor Emeritus University of Missouri David M. Wood Professor Emeritus University of Missouri David A. Leuthold

Professor Emeritus University of Missouri Richard R. Dohm Professor Emeritus University of Missouri

\section{STANLEY KELLEY, JR.}

Stanley Kelley, Jr., a creative scholar and legendary teacher at Princeton University, died on January 17, 2010, at the age of 83 .

Kelley joined the Princeton faculty in 1957 and stayed for more than half a century. His career-long commitment to Princeton, its students, and its faculty made him a model of dedicated university citizenship. He retired from teaching in 1995 but remained active in the Princeton community, participating in colloquia, advising senior thesis students, and working on his final book, a distillation of his career as a student and teacher of party politics. 